\title{
Utilization of Rhizosphere Microbes to Control Empty Panicle Disease in Rice Plants (Oryza sativa L.) invitro
}

\author{
I Made Sudarma*, Ni. Nengah Darmiati and Ni. Wayan Suniti \\ Department of Agroecotechnology Study Program, Faculty of Agriculture, Udayana \\ University/Jl. PB. Sudirman Denpasar-Bali, Indonesia \\ *Corresponding author
}

\section{A B S T R A C T}

Keywords

Empty Panicle disease, inhibition, diversity and dominance index, and rhizosphere

Article Info

\section{Accepted:}

12 May 2021

Available Online:

10 June 2021
Empty panicle disease found in the study was caused by Fusarium sp. which according to reference is $F$. moniliformin (the perfect stage is called Gibberella fujikuroi).The rhizosphere fungus which was successfully isolated and dominated was Penicillium sp. the rhizosphere microbial diversity index was 0.5517 with a dominance index dominance of 0.8264.The inhibition of rhizosphere fungi against pathogens (Fusarium sp.) A. flavus has the highest inhibition of $88.89 \pm 0.09 \%$, followed by Penicillium sp. 2 at $88.89 \pm 0.08 \%$, Penicillium sp. 4 was $88.89 \pm 0.05$, Penicillium sp. 3 was the same as Penicillium sp. 5 each with inhibition of $88.89 \pm 0.04 \%$ and the lowest Streptomyces sp. 1 of $77.78 \pm 0.01 \%$ at 10 dai (days after inoculation).

\section{Introduction}

Fusarium disease is common in wet climates in Asia. This disease is known as "Fusarium blight" or "Gibberella blight "which can be interpreted as "Fusarium blight". In Japan, this disease is known as "bakanae" because plant growth deviates from normal (Semangun, 1991).

This disease has resulted in a rice yield loss of up to $20 \%$ when the disease explodes. For example in Japan, yield losses of up to 20-
$50 \%$ were observed. In India it reaches $15 \%$ and in Thailand it reaches 3.7\% (IRRI, 1983). Fusarium disease in Indonesia has been reported since 1938, in that year in Cirebon the Untung rice type which was resistant to "mentek" was severely attacked by the fungus Fusarium and Dreschlera (Semangun, 1991).

Bekanae disease comes from Japanese which means "Foolish seedling". Bakanae disease in rice is known to occur in almost all rice plantations in the world. This disease was first recognized in 1828 but in 1898 it was certified 
by Shotaro Hori that the disease was caused by a fungus. In the United States it was observed in 1999. Until 1890 it was believed that this disease was caused by Fusarium moniliformis, while later that the disease was caused by other species of Fusraium fungi, among them Fusarium fujikori which was responsible for these symptoms.

It is interesting to note that some Fusarium species are associated with diseased plants but do not contribute to the development of disease symptoms. Fusarium fujikori has a number of hosts scattered throughout the world (Naeem et al., 2016).

The causative agent of bakanae "Fusarium fujikuroi" produced secondary metabolite fusaric acid and gibberellic acid (GA) which produced higher plantlets in the field with empty panicles.

For the management of this disease a variety of physical, chemical and biological methods are used, chemical methods are preferred over other methods due to the complexity of the disease and the wider range of pathogenic hosts.

In recent years, the incidence of bakanae has increased from season to season in Punjab and Haryana. The development and application of appropriate management techniques will be a strong challenge in the future in crop-based cropping systems in various places in Punjab and Haryana (Katoch et al., 2019).

\section{Materilas and Methods}

\section{Place and time of research}

The research was carried out in two places: 1) looking for specimens of sick and healthy plants from rice plants grown on Jalan Siulan, East Denpasar. 2) Plant Disease Science Laboratory and Agricultural Biotechnology
Laboratory. The research was conducted from January to March 2020.

\section{Rhizosphere Fungi Isolation}

Isoilation of rhizosphere fungi, take 1 gram of soil from the rhizosphere of healthy rice plants, then do the dilution level up to 10-3.

After that the colony is calculated by using the cfu (colony forming unit) unit. After 2 days, the colonies were separated into Petri dishes which had previously been filled with antibacterial antibiotics, namely livoploxasin with a concentration of $0.1 \%(\mathrm{w} / \mathrm{v})$.

After 3 days the fungus is ready to be identified by microcoscopic which previously tested the inhibition of rhizosphere fungi with pathogens and looking for the best fungi to be used as antagonists.

\section{Rhizosphere Microbial Identification}

The stored rhizosphere fungi were then grown on a Petri dish containing PDA and repeated 5 times. The cultures were incubated in a dark room at room temperature $\left( \pm 27^{\circ} \mathrm{C}\right)$. Isolates were identified macroscopically after 3 days of age to determine colony color and growth rate, and microscopic identification to determine septa in hyphae, spore/conidia shape and sporangiophores.

Identification of fungi using the reference book Samson et al., 1981; Pitt and Hocking, 1997; Barnett and Hunter, 1998; and Indrawati et al., 1999.

\section{Determine the Diversity Index and the Domination Index}

The diversity and dominance of rhizosphere microbes can be determined by calculating the Shannon-Wiener diversity index (Odum, 1971) and the dominance of rhizosphere 
microbes is calculated by calculating the Simpson index (Pirzan and Pong-Masak, 2008).

\section{Index of rhizosphere microbial diversity}

The rhizosphere microbial diversity index is determined by the Shannon-Wiener diversity index, namely the formula (Odum, 1971):

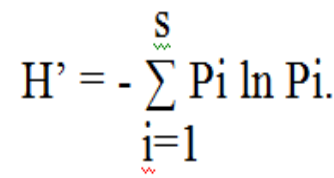

Where:

$\mathrm{H}^{\prime}=$ Shannon-Wiener diversity index

$\mathrm{S}=$ Number of genera

$\mathrm{Pi}=n \mathrm{n} / \mathrm{N}$ as the proportion of species $\mathrm{i}(\mathrm{ni}=$ total number of individuals microbial species i,

$\mathrm{N}=$ number of all individuals in total $\mathrm{n}$ )

The criteria used to interpret the ShannonWiener diversity (Ferianita-Fachrul et al., 2005) are: $H$ 'value <1, means low diversity, $\mathrm{H}^{\prime}$ value $1-3$ means that the diversity is classified as moderate and $\mathrm{H}$ 'value> 3 means that the diversity is classified as height and Table 1.

\section{Dominance index}

The rhizosphere microbial dominance index is calculated by calculating the Simpson index (Pirzan and Pong-Masak, 2008), with the following formula:

$$
\mathrm{C}=\sum_{\mathrm{i}=1}^{\mathrm{s}} \mathrm{Pi}^{2}
$$

Where:
$\mathrm{C}=$ Simpson index

$\mathrm{S}=$ Number of genera

$\mathrm{Pi}=\mathrm{ni} / \mathrm{N}$, namely the proportion of individuals of type $\mathrm{i}$ and all individuals $(\mathrm{ni}=$ total number of individuals of type $i$,

$\mathrm{N}=$ number of individuals in total $\mathrm{n}$ )

Furthermore, the dominance index (D) can be calculated using the $1-\mathrm{C}$ formulation $(\operatorname{Rad} e t$ al., 2009).

The criteria used to interpret the dominance of soil rhizosphere microbial types are: close to 0 = lower index or lower dominance by one rhizosphere microbial species or there are no species that dominate other species, close to 1 $=$ large index or tend to be dominated by several rhizosphere microbial species (Pirzan and Pong-Masak, 2008).

\section{Prevalence}

Prevalence can be calculated by dividing the number of a given rhizosphere microbial population divided by the entire population times $100 \%$.

\section{Inhibition Test against Pathogens}

Each of the rhizosphere microbes found were tested for their inhibitory power against the growth of pathogenic fungi using a dual culture technique (in one Petri dish, each one of the pathogenic fungi was grown flanked by two rhizosphere fungi).

The inhibition power can be calculated as follows (Dollar, 2001; Mojica-Marin et al., 2008):

Inhibition ability $=\mathrm{A}-\mathrm{B} / \mathrm{A} \times 100 \% . \quad(\mathrm{A}=$ Colony diameter of patogen in single culture $(\mathrm{mm})$ and $\mathrm{B}=$ colony diameter of pathogen in dual culture $(\mathrm{mm})$. 


\section{Results and Discussion}

\section{Diseases Study}

\section{Symptom}

Diseases that are seen in growing panicles from flag leaves show emptiness, panicles appear to grow straight with empty grains (not filled). The empty panicle (hollow) is a sign that there is a clogged food channel from the root to the stem, and from the stem to the panicle. Upon close observation, it appears that there is a brownish colour at the base of the panicle attached to the stem (Figure 1). The base of the sliced stems (Figure 1B; left) was sliced and then cultured in a Petri dish filled with PDA, after 2 days white mycelium grew (Figure 2).

Figure 1. Symptoms of disease with empty panicles (arrows) (A), and (B) brown panicles (arrows) at the base of the panicles (left) and healthy panicles (right) (personal source)

\section{Cause of disease}

Disease caused by Fusarium sp. based on microscopic observations found crescentshaped macroconidia with a size of 5-10 x 20$40 \mu \mathrm{m}$ (Figure 2B). Mycelium is white with a little orange colour in the middle, it is a sign that the mycelium is Fusarium (Figure 2A).

\section{Rhizosphere Microbial Colonies and Prevalence}

The rhizosphere fungi that were isolated were Penicillium sp., 3 x $10^{3} \mathrm{cfu}$, followed by Streptomyces sp. (Actinimycetes) and A. flavus each as much as $2 \times 10^{3} \mathrm{cfu}$, and Aspergillus sp., A. nidulan, A. niger, and Nicordia sp., (Actinomycetes) each as much as $1 \times 10^{3} \mathrm{cfu}$. The highest prevalence was obtained from Penicillium sp. with a value of 27.27\% (Table 2; Figure 3).

\section{Diversity Index and Domination Index}

The rhizosphere microbial diversity index was 0.5517 with a dominance index of 0.8264 (Table 3). The diversity index obtained according to the criteria of Table 1, it was found that the condition of the community structure was unstable, with a very bad category with a scale of 1 (Table 1). While the index of dominance is close to one, this means that there are species that dominate, namely Penicillium sp. amounted to $27.27 \%$ (Table 2).

\section{Inhibition Ability of Rhizosphere against Pathogen}

Inhibition of rhizosphere fungi against pathogens (Fusarium sp.) All have inhibition against pathogens except Nucordia sp. at 10 hsiA. flavus had the highest inhibitory power of $88.89 \pm 0.09 \%$, followed by Penicillium sp. 2 of $88.89 \pm 0.08 \%$, Penicillium sp. 4 of 88.89 $\pm 0.05 \%$, and Penicillium sp. 3 of $88.89 \pm$ $0.04 \%$ (Table 4).

The disease caused by Fusarium in rice is bekanae, this disease was studied in 1828 and named in 1898 which is believed to be caused by Fusarium moniliformin (its perfect stage is called Gibberella fujikuroi) but other Fusariums were also found to cause this disease (Naeem et al., 2016).

Bekanae disease, also known as "Foolish seedling disease", appears as an important disease that causes significant disease in rice plants in the world (Katoch et al., 2019).

Bekanae disease can reduce the yield from 3.0 to $95.4 \%$ and the percentage of disease varies according to the cultivar planted in the region in Asia. One of the problems with rice cultivation, especially in India for several years now and is a more serious threat to sustainable rice production in other parts of the world rice cultivation (Gupta et al., 2015). 
Table.1 Environmental quality weighted assessment criteria (Tauruslina et al., 2015)

\begin{tabular}{|c|c|c|c|}
\hline Diversity index & $\begin{array}{c}\text { The condition of the } \\
\text { community structure }\end{array}$ & Category & Scale \\
\hline$>\mathbf{2 , 4 1}$ & Very stable & Very good & 5 \\
\hline $\mathbf{- 2 , 4}$ & More stable & good & 4 \\
\hline $\mathbf{1 , 2 1}-\mathbf{1 , 8}$ & Pretty stable & Moderate & 3 \\
\hline $\mathbf{0 , 6 1}-\mathbf{1 , 2}$ & Less stable & Bad & 2 \\
\hline$<\mathbf{0 , 6}$ & Unstable & Very bad & 1 \\
\hline
\end{tabular}

Table.2 Diversity index and dominance index of rhizosphere microbial

\begin{tabular}{|c|c|c|c|c|c|}
\hline $\begin{array}{c}\text { Name of } \\
\text { microbials }\end{array}$ & Population & pi/P & Ln (pi) & pi/P x ln (pi/P) & (pi/P) \\
\hline Penicillium sp. & 3 & 0.2727273 & 1.09861229 & 0.299621533 & 0.07438017 \\
\hline Aspergillus sp. & 1 & 0.0909091 & 0 & 0 & 0.00826446 \\
\hline $\begin{array}{c}\text { A. nidulans } \\
\text { Streptomyces sp. } \\
\text { (Actinomycetes) }\end{array}$ & 1 & 0.0909091 & 0 & 0 & 0.00826446 \\
\hline A. niger & 1 & 0.1818182 & 0.69314718 & 0.12602676 & 0.03305785 \\
\hline A. flavus & 2 & 0.1818182 & 0.69314718 & 0.12602676 & 0.03305785 \\
\hline $\begin{array}{c}\text { Nucordiasp. } \\
\text { (Actinomycetes) }\end{array}$ & 1 & 0.0909091 & 0 & 0 & 0.00826446 \\
\hline & 11 & & & & 0.00826446 \\
\hline
\end{tabular}

$\mathrm{H}=$ diversity index 0.55168 and dominance index $1-0.1736=0.8264$

Table.3 Inhibition ability of rhizosphere microbial against pathogen

\begin{tabular}{|c|c|c|c|c|c|}
\hline No & $\begin{array}{l}\text { Name of rhizospehere } \\
\text { microbials }\end{array}$ & $\begin{array}{c}\mathbf{4} \text { dai }(\%) \\
(\text { control } \\
\text { diameter }=3,5 \\
\mathrm{~cm})\end{array}$ & $\begin{array}{c}6 \text { dai }(\%) \\
\text { (control } \\
\text { diameter= } 5 \\
\mathrm{~cm})\end{array}$ & $\begin{array}{c}8 \text { dai }(\%) \\
\text { (control } \\
\text { diameter } 5,5 \\
\text { cm) }\end{array}$ & $\begin{array}{c}10 \text { dai }(\%) \\
\text { (control } \\
\text { diameter } 9 \\
\mathrm{~cm})\end{array}$ \\
\hline 1 & Penicillium sp.1 & $40 \pm 0.12$ & $50 \pm 0.08$ & $66.67 \pm 0.09$ & $77.78 \pm 0.09$ \\
\hline 2 & Nocardia sp. & - & - & - & - \\
\hline 3 & Penicillium sp.2 & $40 \pm 0.08$ & $50 \pm 0.03$ & $83.33 \pm 0.08$ & $88.89 \pm 0.08$ \\
\hline 4 & A. flavus 1 & $60 \pm 0.11$ & $75 \pm 0.04$ & $83.33 \pm 0.08$ & $88.89 \pm 0.09$ \\
\hline 5 & Streptomyces sp. 1 & $40 \pm 0.09$ & $50 \pm 0.05$ & $66.67 \pm 0.07$ & $77.78 \pm 0.01$ \\
\hline 6 & Penicillium sp. 3 & $60 \pm 0.03$ & $75 \pm 0.06$ & $83.33 \pm 0.03$ & $88.89 \pm 0.04$ \\
\hline 7 & Penicillium sp. 4 & $40 \pm 0.05$ & $63 \pm 0.12$ & $83.33 \pm 0.04$ & $88.89 \pm 0.05$ \\
\hline 8 & Streptomyces sp. 2 & $40 \pm 0.08$ & $63 \pm 0.13$ & $75 \pm 0.05$ & $83.33 \pm 0.06$ \\
\hline 9 & Aspergillus sp. 1 & $40 \pm 0.12$ & $63 \pm 0.14$ & $75 \pm 0.12$ & $83.33 \pm 0.05$ \\
\hline 10 & Aspergillus sp. 2 & $60 \pm 0.09$ & $75 \pm 0.11$ & $83.33 \pm 0.11$ & $88.89 \pm 0.02$ \\
\hline 11 & A. flavus 2 & $60 \pm 0.11$ & $63 \pm 0.15$ & $75 \pm 0.12$ & $83.33 \pm 0.01$ \\
\hline 12 & Penicillium sp.5 & $40 \pm 0.13$ & $50 \pm 0.08$ & $83.33 \pm 0.18$ & $88.89 \pm 0.04$ \\
\hline
\end{tabular}

dai $=$ days after inoculation 
Fig.1 Symptoms of disease with empty panicles (arrows) (A), and (B) brown panicles (arrows) at the base of the panicles (left) and healthy panicles (right) (personal source)
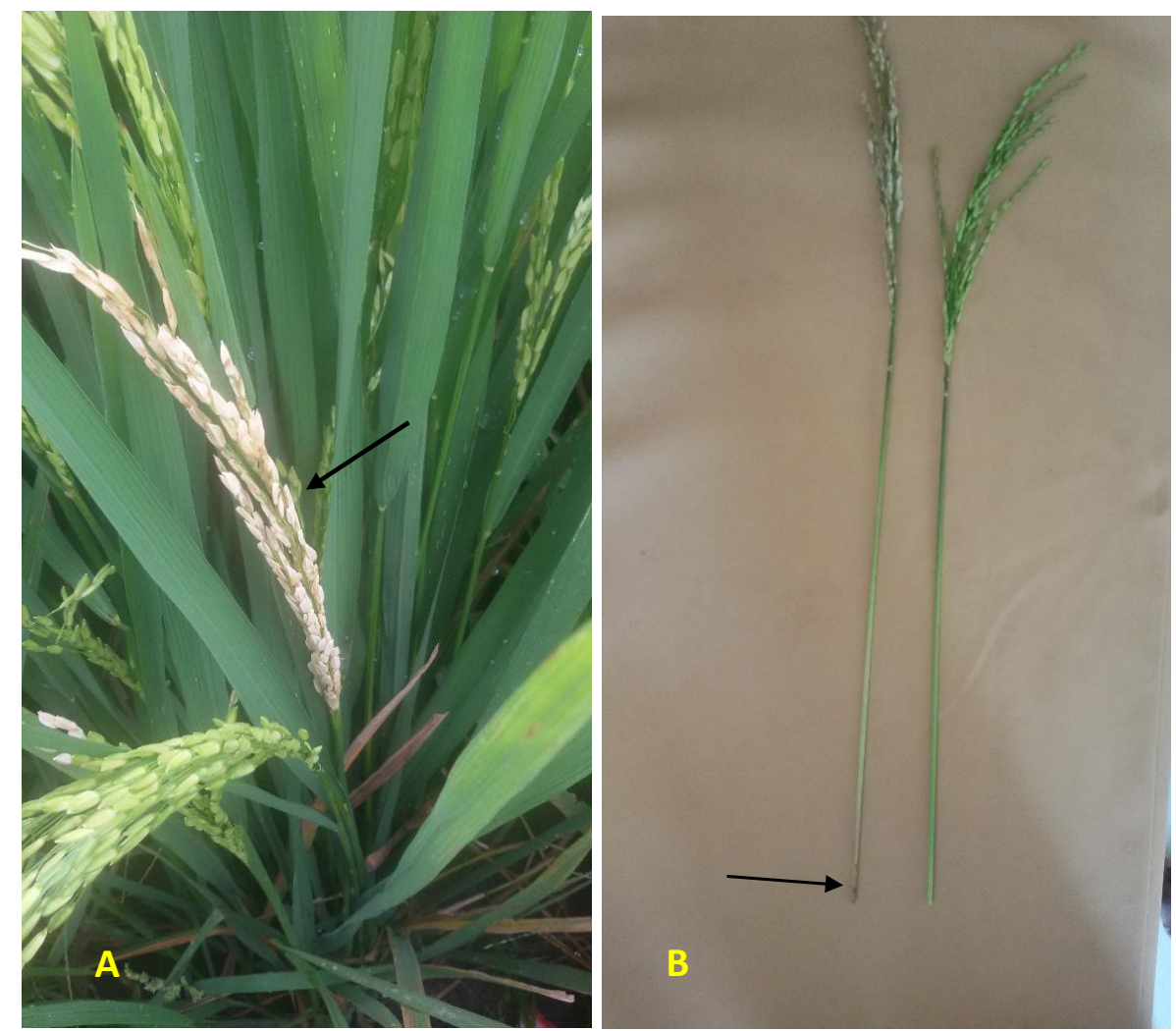

Fig.2 Brown panicle stalks were sliced and then placed in a Petri dish containing PDA (A) media, and (B) the fungal macromonidia Fusarium sp.
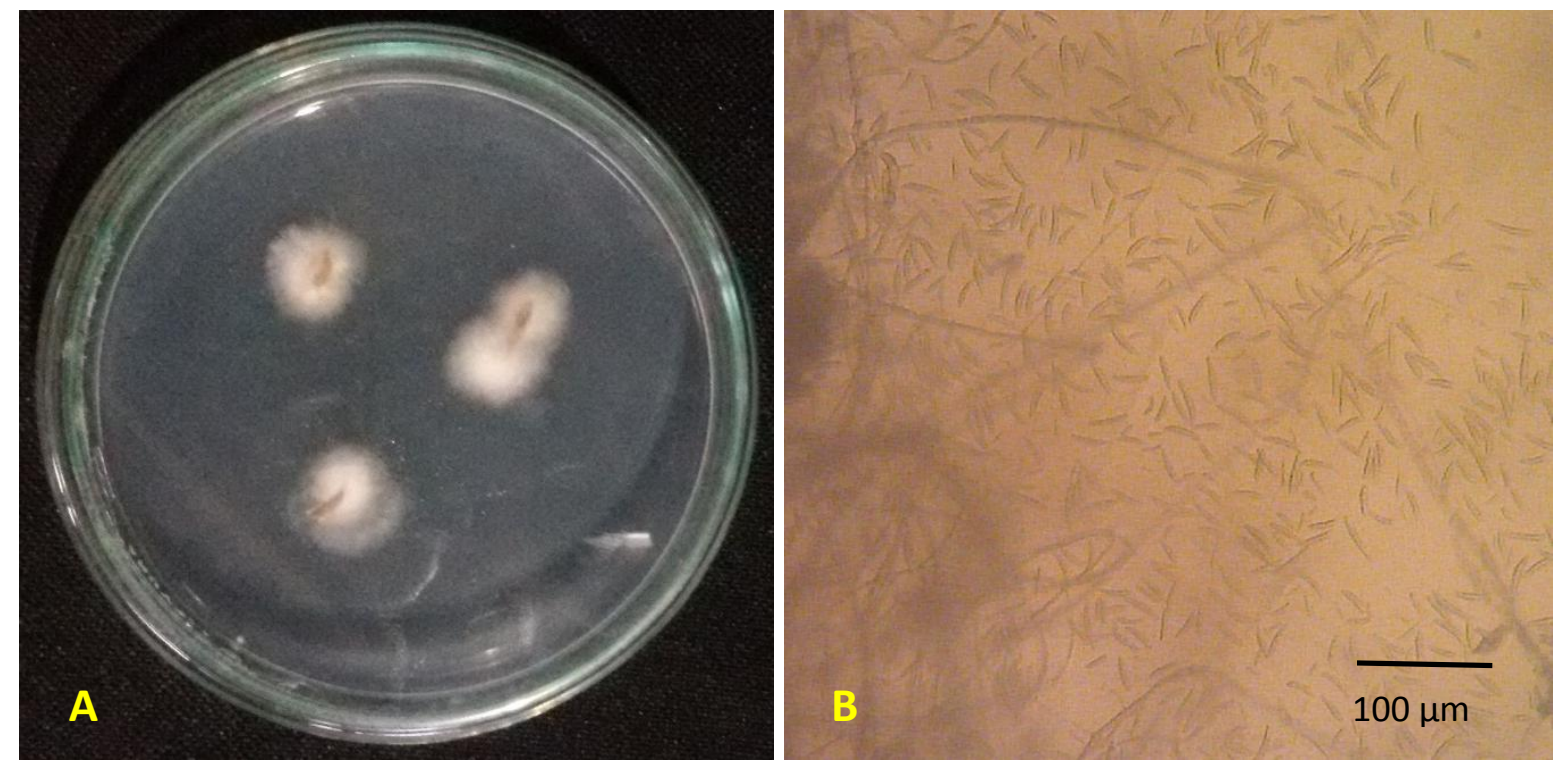
Fig.3 Number of microbial colonies in healthy rice plant rhizosphere

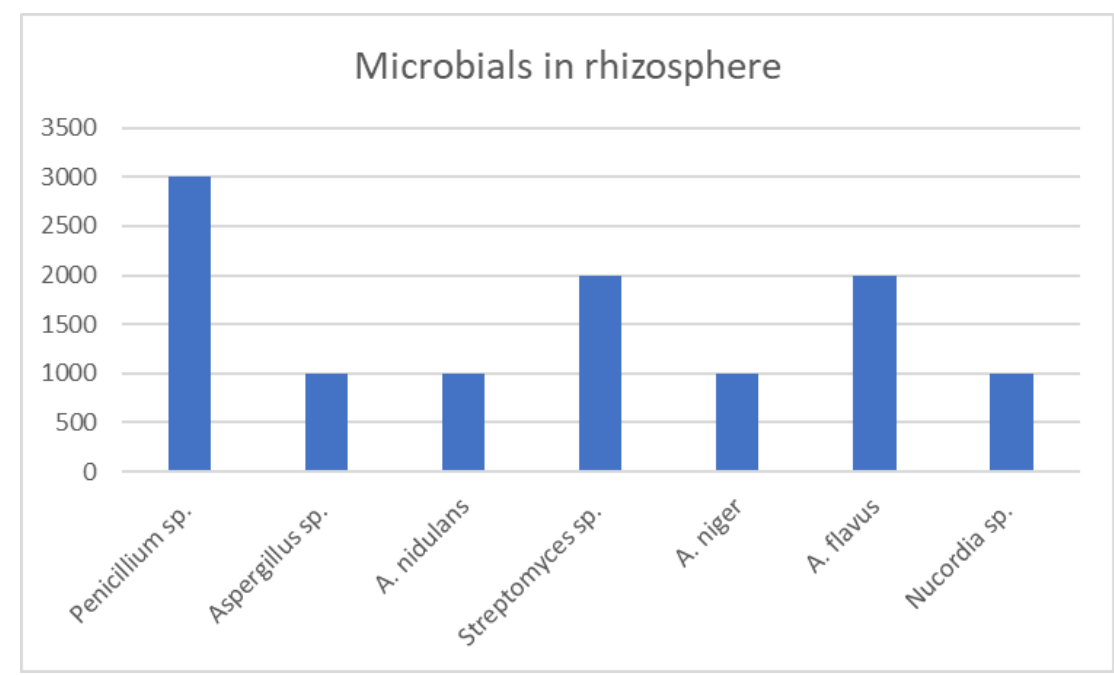

The rhizosphere fungi found in the roots of healthy chilies were Penicillium digutatum of $30 \times 10^{3} \mathrm{cfu}$, followed by Penicillium expansum of $12 \times 10^{3} \mathrm{cfu}, 6 \times 10^{3} \mathrm{cfu}$ of Trichoderma harzianum, then A. nidulan, A, niger, Penicillium sp., And T. virens each as much as $3 \times 10^{3} \mathrm{cfu}$ (Sudarmaet al., 2015). Penicillium and Aspergillus are fungi that exist and spread throughout the world in the soil, and have always been there. This fungus produces a lot of spores so that it is easily carried away by wind and other vectors.

The highest inhibition of rhizosphere fungi against pathogens (Phytophthora capsici) was achieved by Aspergillus sp. amounting to $75.93 \pm 2.62 \%$ (Sudarma et al., 2019). The results of Vasanthakumari and Shivanna's (2011) research on rhizosphere fungi that were most commonly found were Aspergillus, Chaetomium, Penicillium and Trichoderma fungi on grass roots. The diversity of microbes and types in the rhizosphere largely determines the interactions between microbes that help plant health and quality, has implications for the success of suppressing disease (Garbeva et al., 2004).

Based on the results and discussion above, it can be concluded as follows: Empty panicle disease found in the study was caused by $F u$ sarium sp. which according to reference is $F$. moniliformin (the perfect stage is called Gibberella fujikuroi). The rhizosphere fungi that were isolated were Penicillium sp., $3 \mathrm{x}$ $10^{3} \mathrm{cfu}$, followed by Streptomyces $\mathrm{sp}$. (Actinimycetes) and A. flavus each as much as 2x103 cfu, and Aspergillus sp., A. nidulan, A. niger, and Nicordia sp., (Actinomycetes) each as much as $1 \times 10^{3} \mathrm{cfu}$. The rhizosphere microbial diversity index was 0.5517 with a dominance index of 0.8264 . Inhibition of rhizosphere fungi against pathogens (Fusarium sp.)

All have inhibition against pathogens except Nucordia sp. at 10 dai A. flavus had the highest inhibitory power of $88.89 \pm 0.09 \%$, followed by Penicillium sp. 2 of $88.89 \pm$ $0.08 \%$, Penicillium sp. 4 of $88.89 \pm 0.05 \%$, and Penicillium sp. 3 amounted to $88.89 \pm$ $0.04 \%$ at 10 days after inoculation.

\section{Acknowledgments}

Thank you to the Chancellor of Udayana University for the assistance and opportunities provided during the research. The Dean of the Faculty of Agriculture of Udayana University and the Chair of the Institute for Research and 
Community Service, the coordinator of the Agroecotechnology Study Program for his assistance and cooperation during the research until completion.

\section{References}

Barnett, H. L. and B. B. Hunter. 1998. Illustrated Genera of Imperfect Fungi. Fourth Edition. APS Press. The American Phytopththological Society St. Paul. Minnesota.

Dolar, F. S. 2001. Antagonistic effect of Aspergillus melleus Yukawa on soilborne pathogens of Chickpea. Tarim Bilimleri Dergisi, 8(2): 167-170.

Ferianita-Fachrul, M., H. Haeruman, dan L. C. Sitepu. 2005. Komunitas Fitoplankton Sebagai Bio-Indikator Kualitas Perairan Teluk Jakarta. FMIPAUniversitas Indonesia Depok.

Gardeva, P., J. A. van Veen, and J. D. van Elsas. 2004. Microbial Diversity in Soil: Selection ofMicrobial Populations by Plant and Soil Type and Implications for Disease Suppressiveness. Annu. Rev. Phytopathol. 42:243-70.

Gupta, A. K., I. S. Solanki, B. M. Bashyal, Y. Singh and K. Srivastava. 2015. Bakanae of rice-an amerging disease in Asia. The Journal of Animal and Plant Science 25(6): 1499-1514.

Indrawati. G., R. A. Samson, K. Van den Tweel-Vermeulen, A. Oetari dan I. Santoso. 1999. Pengenalan Kapang Tropik Umum. Yayasan Obor Indonesia. Universitas Indonesia (University of Indonsia Culture Collection) Depok, Indonsia dan Centraalbureau voor Schirmmelcultures, Baarn, The Netherlands.

International Rice Risearch Institute (IRRI). 1983. Rice Blast. Rice Science for a Better World. Rice Fact Sheet.

Katoch P., A. Katoch, M. Paudel and S.
Upreti. 2019. Bakanae of Rice: A Serious Disease in Punjab. Int. J. Curr. Microbiol. App. Sci 8(5): 129-136.

Mojica-Marin, V., H. A. Luna-Olvera, C. Fco, Sandoval-Coronado, B. PereyraAlférez, H. Lilia, Morales-Ramos, E. Carlos, Hernández-Luna and G. O. Alvarado-Gomez. 2008. Antagonistic activity of selected strains of Bacillus thuringiensis against Rhizoctonia solaniof chili pepper. African Journal of Biotechnology, 7 (9): 1271-1276.

Naeem M., M. Iqbal, N. Parveen, Sami-UlAllh, Q. Abbas, A. Rehman and M. Sad. 2016. An over View of Bakanae Disease of Rice. American-Eurasian J. Agric. \& Environ. Sci., 16 (2): 270277.

Odum, E. P. 1971. Fundamentals of Ecology. Third Edition. W.B. Saunders Company. Philadelphia, Toronto, London. Toppan Company, Ltd. Tokyo, Japan.

Pirzan, A. M., dan P. R. Pong-Masak. 2008. Hubungan Keragaman Fitoplanktondengan Kualitas Air di Pulau Bauluang, Kabupaten Takalar, Sulawesi Selatan. Biodiversitas, 9 (3) 217-221.

Pitt, J. I. and A. D. Hocking. 1997. Fungi and Food Spoilage. Blackie Avademic and Professional. Second Edition. LondonWeinhein-New York-TokyoMelboune-Madras.

Rad, J. E., M. Manthey and A. Mataji. 2009. Comparison of Plant Species Diversity with Different Plant Communities in Deciduous Forests. Int. J. Environ. Sci. Tech, 6(3): 389-394.

Samson, R. A., E. S. Hoekstra, and C. A. N. Van Oorschot. 1981. Introduction to Food-Borne Fungi. Centraalbureau Voor-Schimmel cultures. Institute of The Royal Netherlands. Academic of Arts and Sciences.

Semangun, H. 1991. Penyakit-Penyakit 
Tanaman Pangan di Indonesia. Gadjah Mada University Press. Yogyakarta.

Sudarma I M., N.W. Suniti, N. N. Darmiati and I G. N. Bagus. 2019. Mycoflora Potential in Rizospher as Biological Agents to Control Wilt Diseases onPepper Plant(Capsicum Frutescens L.)EPH - International Journal of Agriculture and Environmental Research 5(1): 36-44.

Sudarma, I M., N. M. Puspawati, N. W. Suniti, I N. Wijaya and I G. N. Bagus. 2015. Utilization of rhizosphere fungi to control Fusarium oxysporum f.sp. capsici in vitro. International Journal of Biosciences and Biotechnology 2(2):
83-92.

Tauruslina, E. A., Triszella, Yaherwandi, dan H. Hamid. 2015. Analisiskeane karagaman hayatimusuhalami pada ekosistempadiawah di daeah endemic dan non-endemikwereng batangcokelat Nilaparvarta lugens di Sumatera Barat. Pors Sem NasMasyBiodevIndon 1(3): 581-589.

Vasanthakumari M. M., and M. B. Shivanna, 2011. Fungal Assemblages in the Rhizosphere and Rhizoplane of Grasses of the Subfamily Panicoideae in the Lakkavalli Region of Karnataka, India. Microbes Environ. 26(3): 228236.

\section{How to cite this article:}

I Made Sudarma, Ni. Nengah Darmiati and Ni. Wayan Suniti. 2021. Utilization of Rhizosphere Microbes to Control Empty Panicle Disease in Rice Plants (Oryza sativa L.) In vitro. Int.J.Curr.Microbiol.App.Sci. 10(06): 1-9. doi: https://doi.org/10.20546/ijcmas.2021.1006.001 